proved that the third model of management is the most acceptable for Ukraine in terms of the scale of international tourism and the form of organization of the tourism industry for Ukraine.

It is established that the main objectives of public administration in the field of tourism are: ensuring the rights of citizens enshrined in the Constitution of Ukraine to rest, freedom of movement, recovery and health promotion; safety of tourism, protection of the rights and legitimate interests of tourists, owners or users of land, buildings and structures; creation of favourable conditions for the development of the tourism industry, support for priority areas of tourism. It is emphasized that the priority areas of public administration in the field of tourism are: improving the legal framework for regulating relations in the field of tourism; ensuring the formation of tourism as a highly profitable sector of Ukraine's economy, encouraging national and foreign investment in the development of the tourism industry, creating new jobs; development of inbound and domestic tourism, rural, ecological (green) tourism; expansion of international cooperation, establishment of Ukraine on the world tourist market; creating favourable conditions for tourism development by simplifying and harmonizing tax, currency, customs, border and other types of regulation.

The specifics of mechanisms of regulation and management of potential of the tourist sphere of Ukraine are analyzed. Methods of public administration in the field of tourism are defined. The influence of public organizations on the creation of favourable investment conditions for tourism is analyzed. The system of principles of public administration in the sphere of tourist activity is defined. It is found out that the received information will allow the management of the tourist enterprises to make optimum strategic decisions, to define the best methods of strategic development, measures of competition,

Keywords: public administration, sphere of tourist activity, tourism industry, tourist activity, tourist sphere, tourist service, tourist potential, tourist market.

DOI: $10.33766 / 2524-0323.90 .138-146$ УДК 343:97

І. Б. Медицький,

кандидат юридичних наук, доцент, доцент кафедри кримінального праваавчально-наукового Юридичного інституту Прикарпатського національного університету імені В. Стефаника

(м. Івано-Франківськ, Украӥна)

e-mail: ibm78@ukr.net

iD 1 ttps://orcid.org/ 0000-0002-6720-6658

\title{
ДІЯЛЬНІСТЬ ОРГАНІВ КРИМІНАЛЬНОЇ ЮСТИЦІЇ В СУЧАСНИХ УМОВАХ: «СОБІВАРТІСТЬ» ДЛЯ ДЕРЖАВИ І СУСПІЛЬСТВА
}

У статті розглянуто питання діяльності органів кримінальної юстиції в сучасних умовах, бюджетні асигнування на які підтримано віднести до непрямих (опосередкованих) наслідків злочинності. Виділені негативні моменти, супутні процесу державного фінансування органів кримінальної юстиції (необгрунтована диспропорція фінансового забезпечення підрозділів, невідповідність фінансування окремих органів кримінальної юстиції ефективності їх діяльності, порушення принципу економічної доцільності та помилки в пріоритетах). Здійснено комплексний аналіз порушень та зловживань із боку уповноважених суб'єктів правоохоронної діяльності.

(C) Медицький I. Б., 2020 
Ключові слова: органи кримінальної юстищії, правоохоронні органи, наслідки злочинності, «ціна» злочинності, «собівартість», державний бюджет, асигнування.

Постановка проблеми. Факт наявності системних проблем у діяльності суду та органів кримінальної юстищії отримав свою констатащію на державному рівні. Стратегія реформування судоустрою, судочинства та суміжних правових інститутів на 2015-2020 роки основними перешкодами для належного функціонування прокуратури та кримінальної юстищії визнає таке: недостатню структурну незалежність прокуратури в поєднанні з безкарністю та низьким рівнем підзвітності; відсутність стратегічного планування, належного бюджетного і фінансового управління; недостатній рівень функціональної незалежності та доброчесності прокурорів, потребу в білыш розвинених інструментах управління ефективністю, значно жорсткіших етичних вимогах і дисциплінарних правилах [9]. Вирішення питання низької ефективності досудового розслідування як наслідку недосконалості відповідних правових механізмів, надмірного навантаження на органи досудового розслідування та їх неукомплектованості тощо Стратегія розвитку органів системи Міністерства внутрішніх справ на період до 2020 року виділяє серед сучасних пріоритетів у протидії злочинності [10].

Бюджетні асигнування на діяльність, пов'язану із провадженням досудового розслідування, проходженням судової процедури, виконанням кримінальних покарань тощо відносять до непрямих (опосередкованих) наслідків злочинності, ототожнюючи їх з вимушеною реакцією держави (суспільства) на факт вчинення злочину. Як і будь-яка поведінка, що має свого «замовника/споживача», вона повинна відповідати економічно обгрунтованому співвідношенню «ціна-якість».

Аналіз останніх досліджень і публікацій. Ефективність діяльності органів кримінальної юстищії в сучасних умовах, іï критерії та напрями удосконалення виступили предметом наукових пошуків С. С. Абламського, Л. В. Гаврилюк, О. С. Іщука, А. В. Коваленка, М. Г. Колодяжного, О. М. Литвинова, В. В. Назарова, А. О. Наумової та ін. Аналізу економічного аспекту ефективності діяльності органів кримінальної юстищії приділено проте недостатньо уваги. У контексті загальної проблематики наслідків злочинності залишаються практично невирішеними питання обгрунтованості затрат на правоохоронну діяльність, проведення фінансового аудиту та врахування його результатів, методики оцінки та обсяги компенсацій через порушення прав учасників кримінального провадження, інтерес до яких матиме безпосередне значення для покращення практики протидії злочинності.

Формулювання цілей. Стаття має на меті з'ясувати економічний критерій («собівартість») ефективності діяльності органів кримінальної юстищії в сучасних умовах, у тому числі - розкрити фінансові наслідки для держави і суспільства в результаті допущених порушень та зловживань.

Виклад основного матеріалу. Економічна складова ефективності відіграє важливе значення для досягнення сформульованих започаткованими реформами судоустрою та органів кримінальної юстищії завдань. Основним компонентом державних затрат на судову та правоохоронну діяльність було й залишається фінансування конкретних адресатів реалізащії, причому більша частина бюджетних асигнувань припадає на питання регулювання чисельності їх складу. 
Автором здійснено аналіз бюджетних асигнувань на забезпечення діяльності органів кримінальної юстищії впродовж 2015-2019 рр., притім відзначено динаміку ï росту. Як негативні, виокремлено такі моменти:

1) необгрунтовану диспропорцію при фінансуванні апарату МВС України порівняно з витратами на забезпечення захисту від протиправних посягань, охорону громадського порядку тощо. У 2015 р. із загального бюджету МВС України в 33 млрд. 771 млн. грн. 48,6 \% (або16 млрд. 420 млн. грн.) були віднесені на утримання апарату, що на 10,6 \% білыше витрат на забезпечення захисту від протиправних посягань, охорони громадського порядку та протидії незаконній мігращії в масштабах країни (14 млрд. 672 млн. грн.). Указана практика отримала своє продовження і в наступний період. Так у 2018 р. асигнування на апарат, порівняно 3 попереднім роком, зросли на 74,9 \%, у 2019 р. - на 49,2 \%, аналогічно в показниках до минулого 2018 р.;

2) невідповідність фінансування окремих органів ефективності їх діяльності. У 2019 р. на забезпечення діяльності ДБР передбачено 1 111 261,1 тис. грн. (+70,5 \% у порівнянні із попереднім роком). Загальна сума завданої злочинами збитків і шкоди в 2019 р. становила 4,3 млрд. грн., з яких ДБР відшкодовано 4,6 млн. грн., 750 тис. грн. повернуто в Україну з-за кордону [2]. Результативність діяльності ДБР в економічному, вартісному вираженні (у вигляді повернення до бюджету завданої деліктами шкоди) становить лише $0,11 \%$;

3) порушення принципу економічної доцільності та помилки в пріоритетах, необхідних до розв'язання проблем. До прикладу, державна підтримка в 2019 р. фізкультурно-спортивного товариства «Динамо» України в частині організащії та проведення роботи з розвитку фізичної культури і спорту серед працівників та військовослужбовців правоохоронних органів становила 22 млн. 939 тис. грн., тоді як на наукове та інформаційно-аналітичне забезпечення заходів по боротьбі з організованою злочинністю і корупщією передбачено коштів у 5 (!) разів менше (4 млн. 289 тис. грн.). Тенденція мала продовження і в 2020 р.: 23 млн. 918 тис. грн. проти 5 млн. 914 тис. грн. [11, 12].

Недоліки діяльності органів кримінальної юстищії обгрунтовано відносять до ряду соціальних наслідків злочинності [13, с. 255], зловживання представників правоохоронних і судових органів пропонують включати до непрямого збитку від злочинності [1].

О. М. Литвинов і Є. О. Гладкова вказують, що завдяки існуючій державній політищі правоохоронні органи перетворились на квазілегітимні економічні об'єднання з ознаками корпорацій. Криміналізація правоохоронної сфери в сучасному суспільстві визнається як державними, так і суспільними (політичними) діячами та представниками засобів масової комунікації; про неї свідчать матеріали кримінальних проваджень і журналістських розслідувань, а також результати новітніх кримінологічних досліджень [6, с. 91]. Поділяючи позищію авторів щодо наявності кризових, системних проблем у діяльності органів кримінальної юстищії, усе ж таки їх оцінка правоохоронних органів у такому завершеному в часі статусі видається передчасною.

Як зауважує М. Г. Колодяжний, такий економічний показник, як рентабельність, невиправдано ігнорується при оцінщі роботи правоохоронних органів. В Україні поки що не сформована фінансова культура населення, що має тягнути відповідальне витрачання коштів із боку державних органів. Аналогічно можна вести 
мову про недієвий аудит фінансової діяльності органів кримінальної юстищії. ІІї окремі напрями мають ознаки нецільового й неефективного використання бюджетних асигнувань [5, с. 88]. Підтримуючи позищію науковця щодо рентабельності, як різниці між «ціною» злочинності й доходами (прямими і непрямими), одержаними в перебігу іï запобігання, зауважимо, що на їі остаточне визначення суттєво впливатимуть злочинні порушення та зловживання з боку уповноважених суб'єктів органів кримінальної юстищії, про що йтиме мова далі.

Автором здійснений аналіз судової практики розгляду справ у спорах про не договірні зобов' язання (відшкодування шкоди, завданої незаконними рішеннями, діями чи бездіяльністю органу, що здійснює оперативно-розшукову діяльність, досудове розслідування, прокуратури або суду), період ухвалення (постановлення): 01.01 .2019 31.12.2019 pp. Сума до стягнення за рахунок бюджетних асигнувань склала понад 15 млн. грн. Переважну більшість серед допущених порушень законності із постановлених 64 рішень утворюють незаконне повідомлення про підозру та перебування під слідством/судом - 87,5 \%, далі йдуть такі: інші процесуальні дії, що обмежують права громадян - 18,75 \%, незаконне взяття і тримання під вартою - 14 \%, бездіяльність органів досудового розслідування - 10,9\%, незаконнепроведення в ході кримінального провадження обшуку - 9,3 \%, незаконне накладення арешту на майно - 7,8 \% (зазначені відсотки пояснюються поєднанням у рішеннях декількох різновидів порушень - I. М.).

Серед 7160 985,4 тис. грн., виділених, до прикладу, у 2019 р. на здійснення прокурорсько-слідчої діяльності, підготовка та підвищення кваліфікації кадрів прокуратури сума в 15 млн. грн. видається часткою, не вартою уваги. Проте, це є так тільки на перший погляд. Оцінка описаної поведінки працівників органів кримінальної юстищії та суду повинна здійснюватися не тільки з огляду на абсолют недопустимості порушень принципу законності, але і враховувати економічну складову. По-перше, звертає на себе увагу високий середній показник виплат за кожним випадком судового захисту - 234 тис. 617 грн. По-друге, середньомісячні витрати на заробітну плату прокурорсько-слідчого працівника (крім військовослужбовця) у 2019 р. склали 33 622,3 грн. (403 467,6 грн. на рік - I. М.), при відхиленні чисельності їх працівників проти затвердженої в паспорті бюджетної програми кількості (- 967) [3]. Компенсаційні виплати держави могли б послугувати еквівалентом річної заробітної плати ще 37 прокурорсько-слідчих працівників або ж матеріальним підгрунтям для заохочення за високу якість досудового розслідування тощо. По-трете, до авторської добірки потрапила лише частина випадків захисту громадянами порушених прав та інтересів через незаконні дії органів кримінальної юстиції і суду. У багатьох інших захист не відбувається, 3 огляду на недотримання положень ч. 1 ст. 11 Закону України «Про порядок відшшкодування шкоди, завданої громадянинові незаконними діями органів, що здійснюють оперативно-розшукову діяльність, органів досудового розслідування, прокуратури і суду», згідно з якою орган, що здійснює оперативно-розшукову діяльність, слідчий, прокурор або суд, у разі виникнення права на відшккодування завданої шкоди, зобов'язані (виділення моє - I. М.) роз'яснити особі порядок поновлення іiі порушених прав чи свобод та відшкодування завданої шкоди. Уповноважений суб'єкт, одночасно з повідомленням про закриття справи в стадії дізнання й досудового слідства або з копією виправдувального вироку, що набрав законної сили, або постановою (ухвалою) суду (судді), направляс громадянину повідомлення, у якому роз'яснює, куди і протягом якого строку можна звернутися за відшшкодуванням шкоди й 
поновленням порушених прав. Не зайвим буде зазначити, що в 2019 р. у державному бюджеті на відшкодування шкоди, завданої громадянинові незаконними діями органів дізнання, досудового слідства, прокуратури і суду, відшкодування громадянинові вартості конфіскованого та безхазяйного майна, стягнутого в дохід держави, відшкодування шкоди, завданої фізичній чи юридичній особі незаконними рішеннями, діями чи бездіяльністю органів державної влади, їх посадових і службових осіб передбачено 50 млн. грн. (!) [11].

У сфері кримінального судочинства можна зустріти факти, коли з різних необ’єктивних причин допускаються повторні допити свідків, пов' язані з відривом їх від виробнищтва; огляди, відтворення, обшуки, дорогі експертизи і навіть провадження додаткового розслідування та повторний судовий розгляд кримінальних справ, зважаючи на помилки і недоліки при первинному їх розгляді. 3 такими фактами завжди пов'язуються зайві матеріальні, трудові та моральні витрати. І це, як правило, трапляється з вини працівників, що здійснюють кримінальне судочинство [8, с. 36].

Незабезпечення «якості» кримінального судочинства тягне за собою звернення громадян України до Свропейського Суду з прав людини та рішення, за якими до державного бюджету включаються статті відповідних компенсаційних витрат. Зобов'язання держави в частині охорони права на життя має тісний зв' язок із ії процесуальним аспектом - обов' язком забезпечити ефективне розслідування за фактом смерті за підозрілих обставин, причому висновки слідства повинні грунтуватися на ретельному, об'єктивному та безсторонньому аналізі всіх елементів. Автором проведено контент-аналіз 43 рішень ССПЛ (2006-2019 роки), за висновками яких констатоване порушення Україною процесуального аспекту ст. 2 Конвенщії про захист прав людини й основоположних свобод. Найбілыш типовими недоліками в роботі правоохоронних органів, допущення яких стало підставою для присудження заявникам компенсації в розмірі 647694 євро, стали такі: надмірна тривалість кримінального розслідування та його недоліки (неодноразові відмови в порушенні кримінальних справ; неодноразові повернення справи для проведення додаткового розслідування; несвоєчасність проведення експертиз; їх чисельність, яка свідчить про відсутність комплексного підходу до збору доказів на стадії досудового слідства; неодноразовість призначення експертиз одного виду одним слідчим; відсутність належної швидкості та сумлінності, що призвело до втрати важливих доказів та зниження ймовірності успішності слідства; неодноразове невиконання працівниками міліщії вказівок вищестоящих органів та несистемний підхід до збирання доказів; відсутність можливості виправити недоліки розслідування), постійне відкладення судових засідань під час судового розгляду справи, тривалість періоду розслідування та судового розгляду справи.

Нескінченні порушення прав учасників кримінального провадження під час досудового розслідування та в судовому провадженні в майбутньому неминуче будуть використані в позовах до ЄСПЛ, що завдасть значних матеріальних й іміджевих збитків для України. Прикладом цього є прецедентне рішення Свропейського суду з прав людини, який задовольнив разом усі позови, подані українськими громадянами зі скаргами на невиконання судових рішень українських судів, а це 12 тис. справ. До того ж позови були задоволені без розгляду - за принципом схожості. Свропейський суд 3 прав людини зазначив, що Україна все одно рішень суду фактично не виконує, тому суд уже «заливає» зверненнями з цієї країни й далі так тривати не може [7, с. 427]. 
За висновками Рахункової палати, протягом 2016 - I кварталу 2018 року Державною казначейською службою України на виконання бюджетних програм «Відшкодування шкоди, завданої громадянинові незаконними діями органів дізнання, досудового слідства, прокуратури і суду, відшкодування громадянинові вартості конфіскованого та безхазяйного майна, стягнутого в дохід держави, відшкодування шкоди, завданої фізичній чи юридичній особі незаконними рішеннями, діями чи бездіяльністю органів державної влади, їх посадових і службових осіб», «Заходи щодо виконання рішень суду, що гарантовані державою» в межах бюджетних призначень використано 723 494,9 тис. грн., що, відповідно до законодавства, є збитками державного бюджету. Водночас потреб у бюджетних коштах на відшкодування шкоди громадянам та виконання рішень суду, гарантованих державою, призводять до щорічного збільшення заборгованості держави з виконання рішень судів перед громадянами і підприємствами, підвищує соціальну напругу, зменшує кредит довіри до інституцій держави та ефективного правосуддя [4].

Фінансові компенсації порушених прав громадян збілышують видатки бюджету, змушуючи державу вживати відповідних заходів. Згідно зі ст. 19 Закону України «Про державний бюджет України на 2019 рік», Кабінету Міністрів України надано право реструктуризувати фактичну заборгованість обсягом до 7544562370 грн. за рішеннями судів, виконання яких гарантовано державою, а також за рішеннями Європейського суду з прав людини, прийнятими за наслідками розгляду справ проти України, шляхом видачі фінансових казначейських векселів строком обігу до семи років з відстроченням платежів за такою заборгованістю на один рік та відсотковою ставкою 9,3 \% річних. Для забезпечення захисту прав та інтересів України під час урегулювання спорів, розгляду в закордонних юрисдикційних органах справ за участю іноземного суб'єкта та України, а також забезпечення представництва України у ССПЛ передбачено 762 406,2 тис. грн. Платежі на виконання рішень закордонних юрисдикційних органів, прийнятих за наслідками розгляду справ проти України складають 594 422,7 тис. грн. [11]. Зважаючи на існуючу заборгованість у розмірі 7544562,37 тис. грн. та за умови затвердження в подальшому бюджетних призначень не менше ніж 594422,7 тис. грн., остаточне погашення може відбутися орієнтовно через 12 (дванадцять) років (!).

Висновки. Розмір відвернених та відшкодованих за допомогою органів кримінальної юстищії та суду матеріальних збитків від злочинності, домінанту обгрунтованої економії витрат на їх утримання підставно віднести до ключових критеріїв у процесі оцінки ефективності їх діяльності. Допущені уповноваженими суб'єктами зловживання та грубі порушення принципу законності формують свою частку непрямих (опосередкованих) наслідків злочинності, створюючи, окрім безпосередніх втрат бюджету, й інші негативні зміни нематеріального змісту (іміджеві втрати для держави, «кризу довіри» $з$ боку населення тощо).

\section{Використані джерела:}

1. Голіна В. В. «Ціна» злочинності: що ми про неї знаємо? / В. В. Голіна, Н. В. Сметаніна. Голос України. 2013. № 127 (12 липня). С. 10.

2. Звіт про діяльність Державного бюро розслідувань за 2019 p. URL: https:// www. slideshare.net/DBRPress/2019-231275352 (дата звернення: 18.04.2020). 
3. Звіт про виконання паспорта бюджетної програми (Здійснення прокурорсько-слідчої діяльності, підготовка та підвищення кваліфікації кадрів прокуратури) станом на 1 січня 2020 року. URL: https://www.gp.gov.ua/userfiles/Zviti_pro_vikonannja_pasportiv_byudjetnih _program_po_KPKVK_0901010_0901030_0901040.PDF (дата звернення: 22.03.2020).

4. Звіт про результати аудиту стану використання бюджетних коштів на відшкодування шкоди, завданої фізичним та юридичним особам органами державної влади, та на забезпечення виконання рішень суду, що гарантовані державою: рішення Рахункової палати від 31.05.2018 р. №13-2. URL: https://rp.gov.ua/upload-files/ Activity/ Collegium/2018/ 13_2_2018/zvit_13-2_2018.pdf (дата звернення: 31.03.2020).

5. Колодяжний М. Г. Формула визначення ефективності діяльності Національної поліңіі. Держава і злочинність. Нові виклики в епоху постмодерну ; зб. тез доп. наук.-практ. конф., присвяч. пам'яті віце-президента Кримінологічної асощіації України, професора О. М. Литвака (м. Харків, 23 квіт. 2020 р.) / МВС України, Харків. нац. ун-т внутр. справ ; Кримінол. асоц. України. Харків : ХНУВС, 2020. С. 87-89.

6. Литвинов О. М., Гладкова Є. О. Суб'єкти протидії злочинності як правоохоронні корпорації. Вісник Кримінологічнӧ̈ асоијациї Украӥни. 2019. №1(20). С.90-98.

7. Назаров В. В. Сучасні проблеми дотримання конституційних прав і свобод людини в кримінальному провадженні. Захист праъ ююдини: міжнародний та Вітчизняний досъід: матеріали I Міжнародної науково-практичної конференції (16 травня 2019 року). Київ: Національна академія прокуратури України, 2019. С. 425-428.

8. Нікітін Ю. В., Рощина І. О. Ефективність норм кримінального права у попередженні злочинів: Монографія. К.: ВНЗ «Національна академія управління», 2014. 168 с.

9. Про Стратегію реформування судоустрою, судочинства та суміжних правових інститутів на 2015-2020 роки: Указ Президента України від 20.05.2015 р. № 276/2015. URL: https://zakon.rada.gov.ua/laws/show/276/2015/ print (дата звернення: 20.03.2020).

10. Про схвалення Стратегії розвитку органів системи Міністерства внутрішніх справ на період до 2020 року: розпорядження Кабінету Міністрів України від 15.11.2017 р. №1023p. URL: https:/ / zakon.rada.gov.ua/laws/show/ 1023-2017-p/print (дата звернення: 20.03.2020).

11. Про Державний бюджет України на 2019 рік: Закон України від 23.11.2018 p. № 2629VIII. URL: https://zakon.rada. gov.ua/laws/show/2629-19/print (дата звернення: 14.03.2020).

12. Про Державний бюджет України на 2020 рік: Закон України від 14.11.2019 p. 294-IX. URL: https:/ / zakon.rada. gov.ua/laws/show/294-20 (дата звернення: 19.04.2020).

13. Холыст Б. Криминология. Основные проблемы. М.: Юридическая литература, 1980.261 c.

\section{References:}

1. Holina, V. V. (2013) «Tsina» zlochynnosti: shcho my pro nei znaiemo? V. V. Holina, N. V. Smetanina (Eds.). Holos Ukrain - Voice of Ukraine, 127, 10. [in Ukrainian].

2. Zvit pro diialnist Derzhavnoho biuro rozsliduvan za 2019 r. (2019) N. p. URL: https:// www.slideshare.net/DBRPress/2019-231275352. [in Ukrainian].

3. Zvit pro vykonannia pasporta biudzhetnoi prohramy (Zdiisnennia prokurorsko-slidchoi diialnosti, pidhotovka ta pidvyshchennia kvalifikatsii kadriv prokuratury) stanom na 1 sichnia 2020 roku. (2020) N. p. URL: https://www.gp.gov.ua/userfiles/ Zviti_pro_vikonannja_pasportiv_ byudjetnih_program_po_KPKVK_0901010_0901030_0901040.PDF. [in Ukrainian].

4. Zvit pro rezultaty audytu stanu vykorystannia biudzhetnykh koshtiv na vidshkoduvannia shkody, zavdanoi fizychnym ta yurydychnym osobam orhanamy derzhavnoi vlady, ta na zabezpechennia vykonannia rishen sudu, shcho harantovani derzhavoiu: rishennia Rakhunkovoi palaty vid 31.05.2018 r. №13-2. (2018) N. p. URL: https://rp.gov.ua/upload-files/ Activity/ Collegium/2018/13_2_2018/zvit_13-2_2018.pdf. [in Ukrainian]. 
5. Kolodiazhnyi, M. H. (2020) Formula vyznachennia efektyvnosti diialnosti Natsionalnoi politsii. Derzhava i zlochynnist. Novi ryklyky v epokhu postmodernu; zb. tez dop. nauk.-prakt. konf., prysviach. pam'iati vitse-prezydenta Kryminolohichnoi asotsiatsii Ukrainy, profesora O. M. Lytvaka (m. Kharkiv, 23 kvit. 2020 r.) - State and crime. New challenges in the postmodern era; zb. thesis add. scientificpractical conf., dedicated. in memory of the Vice-President of the Criminological Association of Ukraine, Professor OM Litvak (Kharkiv, April 23, 2020) / MVS Ukrainy, Kharkiv. nats. un-t vnutr. sprav; Kryminol. asots. Ukrainy. Kharkiv: KhNUVS, 87-89. [in Ukrainian].

6. Lytvynov, O. M., Hladkova, Ye. O. (2019) Sub'iekty protydii zlochynnosti yak pravookhoronni korporatsii. Visnyk Kryminolohichnoi asotsiatsii Ukrainy - Bulletin of the Criminological Association of Ukraine, 1(20), 90-98. [in Ukrainian].

7. Nazarov, V. V. (2019) Suchasni problemy dotrymannia konstytutsiinykh prav i svobod liudyny v kryminalnomu provadzhenni. Zakhyst prav liudyny: mizhnarodnyi ta vitchyznianyi dosvid. Materialy I Mizhnarodnoi naukovo-praktychnoi konferentsii (16 travnia 2019 roku)-Protection of human rights: international and domestic experience: materials of the I International scientific-practical conference (May 16, 2019). Kyiv: Natsionalna akademiia prokuratury Ukrainy, 425-428. [in Ukrainian].

8. Nikitin ,Yu. V., Roshchyna, I. O. (2014) Efektyvnist norm kryminalnoho prava u poperedzhenni zlochyniv: Monohrafiia. Kyiv: VNZ «Natsionalna akademiia upravlinnia». [in Ukrainian].

9. Pro Stratehiiu reformuvannia sudoustroiu, sudochynstva ta sumizhnykh pravovykh instytutiv na 2015-2020 roky: Ukaz Prezydenta Ukrainy vid 20.05.2015 r. № 276/2015. (2015) ‥p. URL: https://zakon.rada.gov.ua/laws/show/276/2015/ print. [in Ukrainian].

10. Pro skhvalennia Stratehii rozvytku orhaniv systemy Ministerstva vnutrishnikh sprav na period do 2020 roku: rozporiadzhennia Kabinetu Ministriv Ukrainy vid 15.11.2017 r. №1023-r. (2017) N. p. URL: https://zakon.rada.gov.ua/laws/show/ 1023-2017-r/print). [in Ukrainian].

11. Pro Derzhavnyi biudzhet Ukrainy na 2019 rik: Zakon Ukrainy vid 23.11.2018 r. № 2629VIII. (2018) N. p. URL: https:// zakon.rada. gov.ua/laws/show/2629-19/print. [in Ukrainian].

12. Pro Derzhavnyi biudzhet Ukrainy na 2020 rik: Zakon Ukrainy vid 14.11.2019 r. № 294-IX. (2019) N. p. URL: https:// zakon.rada.gov.ua/laws/show/294-20. [in Ukrainian].

13. Holyst, B. (1980) Kriminologiya. Osnovnye problemy. Moskva: Yuridicheskaya literatura. [in Russian].

Стаття надіӥшла до редколегї 12.07.2020

Медицкий И. Б., доцент кафедры уголовного права учебно-научного Юридического института Прикарпатского национального университета имени В. Стефаника

(г. Ивано-Франковск, Украина)

\section{ДЕЯТЕЛЬНОСТЬ ОРГАНОВ УГОЛОВНОЙ ЮСТИЦИИ В СОВРЕМЕННЫХ УСЛОВИЯХ: «СЕБЕСТОИМОСТЬ» ДЛЯ ГОСУДАРСТВА И ОБЩЕСТВА}

В статъе рассмотрены вопросы деятельности органов уголовной юстиции в современных условиях, бюджетные ассигнования на которые поддержано отнести к непрямым (косвенным) последствиям преступности. Выделены негативные моменты, сопутствующие процессу государственного финансирования органов уголовной юстиции (необоснованная диспропорция финансового обеспечения подразделений, несоответствие финансирования 
отдельных органов уголовной юстиции эффективности их деятельности, нарушение принципа экономической целесообразности и ошибки в приоритетах). Осуществлен комплексный анализ нарушений и злоупотреблений со стороны уполномоченных субъектов правоохранительной деятельности.

Ключевые слова: органы уголовной юстиции, правоохранительные органы, последствия преступности, «цена» преступности, «себестоимость», государственный бюджет, ассигнования.

\author{
Meditsky I., \\ Ph.D., Associate Professor, \\ Associate Professor of the Department of Criminal Law \\ the Law and Educational Institute \\ of The Precarpathian National University \\ named after V. Stefanik \\ (Ivano-Frankivsk, Ukraine)
}

\title{
ACTIVITIES OF CRIMINAL JUSTICE BODIES IN MODERN CONDITIONS: "COST" FOR THE STATE AND SOCIETY
}

The article reveals the cost of criminal justice for the state and society in modern conditions. It is substantiated that the economic component of efficiency plays an important role in achieving the goals formulated by the initiated reforms of the judiciary and criminal justice bodies. The main component of public expenditures on judicial and law enforcement activities was and remains the financing of specific recipients of implementation, and most of the budget allocations fall on the regulation of their number. The author analyzes the budget allocations to ensure the activities of criminal justice bodies during 2015-2019, noting the dynamics of their growth. The following points were singled out as negative: 1) unreasonable disproportion in the financing of the staff of the Ministry of Internal Affairs of Ukraine compared to the costs of protection against illegal encroachments, protection of public order, etc.; 2) inconsistency of financing of separate bodies of efficiency of their activity; 3) violation of the principle of economic expediency and error in the priorities of the problems to be solved.

A comprehensive analysis of violations and abuses committed by authorized law enforcement agencies, which form their share of indirect (indirect) consequences of crime, creating, in addition to direct budget losses, other negative changes of intangible content (image losses for the state, «crisis of confidence» by population, etc.). The cost structure of this behavior is proposed to include damage due to illegal decisions, actions or omissions of the body carrying out operational and investigative activities, pre-trial investigation, prosecution or court at the national or international level.

Keywords: criminal justice bodies, consequences of crime, crime price, cost price. 